\title{
CREATIVITY AND GOD IN WHITEHEAD'S PROCESS PHILOSOPHY
}

\author{
Thomas Hidya TJaYA *
}

\begin{abstract}
The category of creativity unquestionably occupies a central position in Alfred North Whitehead's philosophy of organism. Its employment is hardly surprising given his project to establish a speculative philosophy that is compatible with modern science. This article examines the use of such a category in this project and argues that the separation between creativity and God causes several problems, including the absence of an ontological principle that may ground the interaction of the various elements in this metaphysical scheme. A more fundamental question is also raised concerning the nature of this project, which walks a fine line between philosophy and science.
\end{abstract}

Keywords: Whitehead, creativity, the Category of the Ultimate, metaphysics, Aristotle, organism, God.

Abstrak: Kategori kreativitas jelas memperoleh tempat sentral dalam filsafat organisme Alfred North Whitehead. Kehadiran kategori ini tidaklah mengherankan mengingat usahanya untuk membangun sebuah filsafat spekulatif yang selaras dengan sains modern. Artikel ini hendak mengevaluasi penggunaan kategori ini dan menyampaikan argumen bahwa pemisahan antara kreativitas dan Tuhan memuat sejumlah masalah, termasuk ketiadaan sebuah prinsip ontologis yang dapat menyatukan interaksi berbagai unsur dalam skema metafisika ini. Sebuah pertanyaan lebih mendasar juga diajukan terkait dengan hakikat proyek ini sendiri yang memperlihatkan tipisnya batas antara filsafat dan sains.

Kata-kata Kunci: Whitehead, kreativitas, Kategori Pokok, metafisika, Aristoteles, organisme, Tuhan.

* Thomas Hidya Tjaya, Philosophy Studies Program, Driyarkara School of Philosophy, Cempaka Putih Indah 100 A, Rawasari, Jakarta 10520. E-mail: thdtjaya@gmail.com. 


\section{INTRODUCTION}

It is hard for us, particularly philosophers and scientists, to overlook the creative enterprise that occurs in the universe. If we look into the way living beings have evolved, for example, we cannot but find creativity that is at work in the process. For educators, consultants, coaches, artists, and other professionals too, creativity has increasingly been acknowledged as an important factor in human life for innovations in their fields and new ways of solving problems. For such reasons creativity research has developed into its own field of scientific study. ${ }^{1}$ Yet one may raise the question of how creativity ever fits into a philosophical system. In the early twentieth century an English mathematician and philosopher, Alfred North Whitehead (1861-1947) saw the emergence of modern science and attempted to understand the process involved in it from a philosophical point of view. The result of his thinking is known as process philosophy.

This article purports to examine Whitehead's concept of creativity, which lies at the center of his philosophy, drawing particularly from his mature work, Process and Reality. I will begin with the description of the concept as Whitehead presents it in that work, namely as the Category of the Ultimate, followed by the analysis of the so-called nominalist interpretation of creativity. After the comparison between Whitehead's concept of creativity and Aristotle's notion of matter, I will address the relationship between God and creativity in Whitehead's metaphysical scheme and several problems that may emerge regarding his interpretation. In this section I will bring up Robert C. Neville's criticism of Whitehead's philosophy, in particular the separation between creativity and God. This issue may lead us to another important, yet larger issue regarding the nature of the very project in which Whitehead engages.

1 Marc A. Runco and Steven R. Pritzker, Encyclopedia of Creativity, second edition (London: Elsevier, 2011), p. xxi. See also the various topics discussed in The Routledge Companion to Creativity, edited by Tudor Rickards, Mark A. Runco, and Susan Moger (London and New York: Routledge, 2009). 


\section{CREATIVITY AS THE CATEGORY OF THE ULTIMATE}

In the first pages of Process and Reality, Whitehead points to the distinctive characteristic of his philosophy of organism, namely, creativity. Developing a speculative metaphysics that is more in tune with modern science, he decisively makes process or becoming, instead of fact or being, ultimate:

In all philosophic theory there is an ultimate which is actual in virtue of its accidents. It is only then capable of characterization through its accidental embodiments, and apart from these accidents is devoid of actuality. In the philosophy of organism this ultimate is termed 'creativity;' and God is its primordial, non temporal accident. ${ }^{2}$

For Whitehead, the creative advance of the universe is an inescapable reality that philosophy must take seriously and which traditional metaphysics is inadequate to explain. He sees creativity as permeating the whole universe, and its actuality as manifest in its creatures, namely, actual entities: "Each fact is more than its forms, and each form 'participates' throughout the world of facts. The definiteness of fact is due to its forms; but the individual fact is a creature, and creativity is the ultimate behind all forms, inexplicable by forms, and conditioned by its creatures." $^{3}$

To explain the ontological structure of the universe, Whitehead appeals to three notions that form the Category of the Ultimate, namely, creativity, one, and many. The term 'one' stands for "the singularity of an entity," while the term "many' refers to "disjunctive diversity." 4 The creative, universal process that combines many disparate beings into new unities takes place in virtue of these ultimate categories. For Whitehead, these three notions, as fundamental ideas, presuppose each

2 Alfred North Whitehead, Process and Reality: An Essay on Cosmology, edited by David Ray Griffin and Donald W. Sherburne, corrected edition (New York: The Free Press, 1978), p. 7.

3 Alfred North Whitehead, Process and Reality, p. 20.

4 Alfred North Whitehead, Process and Reality, p. 21. 
other "so that in isolation they are meaningless." 5 That is to say, creativity is not derived from 'one' and 'many,' nor are 'one' and 'many' derived from creativity. Rather, each is required to understand each other.

In Whitehead's metaphysical scheme, it is creativity that brings novelties into the world through its interplay with the 'one' and the 'many.' Without creativity, "there can be no 'many things' which are not subordinated in a concrete reality." ${ }^{\prime 6}$ Novelties in the universe emerge through the continuing process of concrescence involving the 'one' and the 'many':

The ultimate metaphysical principle is the advance from disjunction to conjunction, creating a novel entity other than the entities given in disjunction. The novel entity is at once the togetherness of the 'many' which it finds, and also it is one among the disjunctive 'many' it leaves; it is a novel entity, disjunctively among the many entities which it synthesizes. The many become one, and are increased by one. In their natures, entities are disjunctively 'many' in the process of passage into conjunctive unity. ${ }^{7}$

In the advance from "disjunctive diversity" to "conjunctive" unity, the 'many' entities in the universe, through a creative process, become 'one,' yielding a new actual entity. The appearance of the new completed actual entity adds to the set of "many" entities from which the process began. This is where creativity lies: at the end of the process of concrescence, there is one more entity than before the process began. ${ }^{8}$ Here we find a transition from conjunction back to disjunction again. This is why Whitehead describes the creative advance in terms of the unification of the 'many' and its increase in virtue of the emergence of a new entity: "The many become one, and are increased by one." This creative process

5 Alfred North Whitehead, Process and Reality, p. 3.

6 Alfred North Whitehead, Process and Reality, p. 211.

7 Alfred North Whitehead, Process and Reality, p. 21.

8 Robert C. Neville, "Whitehead on the One and the Many," in Explorations in Whitehead's Philosophy, edited by Lewis S. Ford and George L. Kline (New York: Fordham University Press, 1983), p. 260. 
continues on in such a similar cycle, driving the universe forward into an open-ended future.

It is worth noting that for Whitehead, creativity does not function as an external agency in the creative process. This is because each actual entity has the characteristic of self-determination that is comparable to Spinoza's notion of causa sui: "An actual entity feels as it does feel in order to be the actual entity which it is. In this way an actual entity satisfies Spinoza's notion of substance: it is causa sui. Creativity is not an external agency with its own ulterior purposes. All actual entities share with God this characteristic of self-causation." ${ }^{\prime 9}$ Rather, creativity explains the perpetual "creative advance into novelties" by an appeal to actual entities. ${ }^{10}$ That is to say, all actual entities exhibit an immanent creativity to achieve their subjective aim, and it is through its embodiment in actual entities that creativity can be said to have actuality. That is what Whitehead means when he says that creativity is "conditioned by its creatures." 11 Creativity can only take place through the medium of the activity of actual entities; it 'exists' as realized in matters of fact or its creatures, namely, actual entities.

Thus, in Whitehead's speculative philosophy we find a picture of the world pulsating with many actual entities. Each new actual entity is a fusion of many past entities (as data) that together, through the process of concrescence, form a new reality in the present. ${ }^{12}$ Every entity prehends and picks up the feelings of its perished predecessors, establishing itself as a new active entity. Through the existing order fused with freedom, it creates its own identity and strives for self-actualization. For Whitehead, each actual entity has a drive, as it were, to realize its potentialities,

9 Alfred North Whitehead, Process and Reality, p. 222.

10 See Donald W. Sherburne, ed., A Key to Whitehead's Process and Reality (Chicago: The University of Chicago Press, 1981), p. 33.

11 Alfred North Whitehead, Process and Reality, p. 20.

12 See Whitehead's formulation on this issue in Science in the Modern World: "The general principle is that in a new environment there is an evolution of the old entities into new forms." Alfred North Whitehead, Science and the Modern World (New York: The Free Press, 1967), p. 107. 
achieve its subjective aim, and become actual: "Self realization is the ultimate fact of facts. An actuality is self-realizing, and whatever is selfrealizing is an actuality." 13 Through its mental pole, an actual entity experiences conceptual prehensions in which it grasps eternal objects and realizes the potentialities and values it chooses. Further, we also find in this metaphysics characterized by the "creative advance into novelties" the view of nature as a community of interrelated actual entities. ${ }^{14}$ In virtue of creativity, actual entities are interconnected and linked to one another in nexi and in societies through the process of both concrescence and transition. Whitehead uses the term "together" to indicate $t$ an organism, maintains itself by inputs from its environment.

The idea of creativity, as we find in Process and Reality, has been proposed under a different term in Whitehead's earlier work, Science in the Modern World. In this earlier work Whitehead speaks of creativity as a "substantial activity" that underlies the evolution of complex organisms "from antecedent states of less complex organism." This "substantial activity," he claims, expresses itself in individual embodiments and evolves in achievements of organism. ${ }^{16} \mathrm{He}$ also seems to hold in this work that actual entities, for him, are simply the "attributes" of the substantial activity. ${ }^{17}$ This leaves an impression that creativity is somehow more real than the actual entities.

In any case, Whitehead's philosophy of organism entails a worldview that is characterized by a dynamic process of becoming. That is to say, his metaphysical scheme essentially runs counter to the static and mechanical conception of nature: "The universe is thus a creative advance into novelty. The alternative to this doctrine is a static morpho-

13 Alfred North Whitehead, Process and Reality, p. 222.

14 Cf. Donald W. Sherburne, A Key to Whitehead's Process and Reality, p. 35.

15 Alfred North Whitehead, Process and Reality, p. 21. Cf. Alfred North Whitehead. Science and the Modern World, p. 123.

16 Alfred North Whitehead, Science and the Modern World, p. 107.

17 Alfred North Whitehead, Science and the Modern World, p. 165. 
logical universe."18 In his philosophy of organism, Whitehead replaces the atomistic view of the universe as a simply mechanistic aggregation of parts with "the universal relatedness and reciprocal prehension of all real occasions." 19 He even seems to argue that the becoming is an endless process without ever reaching its terminum: "Neither the God, nor the World, reaches static completion. Both are in the grip of the ultimate metaphysical ground, the creative advance into novelty."20

\section{THE NOMINALIST INTERPRETATION OF CREATIVITY}

The categories of 'one' and 'many' have been part of philosophical problems since the pre-Socratic era. Philosophers in this period such as Parmenides and Democritus discussed whether reality was essentially 'one' (hence, monistic) or 'many' (hence, pluralistic). The discussion concerning the ontological status of the universe in this particular respect generally operates on that polarity, between one and many. In his category of the Ultimate Whitehead includes these two ultimate principles and adds creativity. The addition of the latter has engendered different interpretations regarding the status of creativity as Whitehead sees it.

One of the definitions that Whitehead gives of creativity is that it is "the universal of universals characterizing ultimate matter of fact." 21 One reading of this definition is what John R. Wilcox calls "the nominalist interpretation of creativity." 22 In this view, creativity, apart from actual entities, is simply an empty abstraction or a universal concept for the ultimate activity that takes place in actual entities. William A. Christian, for instance, seems to hold this type of interpretation when he says:

18 Alfred North Whitehead, Process and Reality, p. 222. See his formulation in Science and the Modern World: "The substantial activity is that which is omitted in any analysis of the static factors in the metaphysical situation" (p. 165).

19 Friedrich Rapp, “Whitehead's Concept of Creativity and Modern Science” in Whitehead's Metaphysics of Creativity, edited by Friedrich Rapp and Reiner Wiehl (Albany: State University of New York Press, 1990), p. 71.

20 Alfred North Whitehead, Process and Reality, p. 349.

21 Alfred North Whitehead, Process and Reality, p. 21.

22 John R. Wilcox, “A Monistic Interpretation of Whitehead's Creativity," Process Studies Vol. 20/3 (Fall 1991): 164. 
"Creativity is not an entity. It is not to be found among the categories of existence. Much less is it an actual entity. Rather it is a name for a general fact, namely that the universe is made up of novel concrescences." ${ }^{23} \mathrm{He}$ argues elsewhere that creativity is a "pre-systematic" term which is different from "systematic" terms that Whitehead explains in the Categories of Existence, Explanation, and Obligation. As a "nonsystematic" term, it cannot be used to explain any features of the universe. ${ }^{24}$ Creativity is then merely a general concept drawn from common sense which itself must be elucidated in terms of systematic notions.

Such a nomininalist interpretation of creativity gives rise to some significant problems in understanding the whole system of Whitehead's speculative philosophy. Whitehead surely has good reasons to place creativity, together with 'one' and 'many,' in the Category of the Ultimate, which precedes the other three types of categories. The latter categories, Whitehead says, presuppose the Category of the Ultimate which includes creativity. ${ }^{25}$ The ontological priority of the Category of the Ultimate and its presupposition in the other three categories suggest that creativity which belongs to the initial category is not simply a general concept for creative activity.

Moreover, if the nominalist interpretation were correct, it would violate what Whitehead calls "the ontological principle." ${ }^{26}$ According to this principle, only actual entities can serve as the reasons for any universal feature of the universe. This principle thereby rules out any account other than actual entities to explain any feature of the world. In this respect it would be incorrect in principle to use creativity as an explanatory concept for the creative advance that takes place in the universe. That is to say, creativity cannot function, in Whitehead's meta-

23 William A. Christian, An Interpretation of Whitehead's Metaphysics (New Haven: Yale University Press, 1967), p. 403, emphasis mine.

24 William A. Christian, "The Concept of God as A Derivative Notion," in Process and Divinity: Philosophical Essays Presented to Charles Hartshorne, edited by William L. Reese and Eugene Freeman (LaSalle, Ill.: Open Court, 1964), pp. 182-84.

25 Cf. Alfred North Whitehead, Process and Reality, p. 21.

26 Alfred North Whitehead, Process and Reality, p. 24. 
physical scheme, simply as "a name for a general fact," as the proponents of the nominalist interpretation hold.

\section{CREATIVITY AND ARISTOTLE'S MATTER}

One way to understand Whitehead's concept of creativity in Process and Reality, at least as Whitehead puts it, is by comparing it with Aristotle's notion of 'matter.' This analysis is textually legitimate because Whitehead himself holds that his understanding of creativity is essentially another "rendering" of Aristotelian 'matter.' ${ }^{27}$ The similarity between matter and creativity the Whiteheadian scheme is particularly striking because they are both 'protean' in nature and therefore, need some characterization: "Creativity is without a character of its own in exactly the same sense in which the Aristotelian 'matter' is without a character of its own. It is that ultimate notion of the highest generality at the base of actuality." 28 For Aristotle, matter needs characterization from the 'forms' in order to become a substance. Likewise, Whitehead's creativity would have to be characterized by 'eternal object' in order to become 'real' (or an actual entity). Thus, both matter and creativity are inherently neutral and will not become actual without receiving some characterizing identity from the universals. In this respect we may say that they both function as the principle of individuation. Aristotle's matter guarantees that one substance is numerically distinct from every other substance. ${ }^{29}$ Likewise, Whitehead's creativity warrants the numerical distinctness of one actual

27 Alfred North Whitehead, Process and Reality, p. 31.

28 Alfred North Whitehead, Process and Reality, p. 31.

29 Here one may compare Aristotle's understanding of matter with Lonergan's notion of the "empirical residue." The empirical residue for Lonergan is roughly what is "left over" from the direct act of understanding and grasped only by the senses. By the act of understanding one can grasp the universal shared by many individuals, but not the particular individual itself. Insofar as material particularity and numerical difference among many individuals are known through experience, the empirical residue, as Aristotle's matter does, becomes the principle of individuation. See Bernard Lonergan, Insight: A Study of Human Understanding, Collected Works of Bernard Lonergan, vol. 3, edited by Frederick E. Crowe and Robert M. Doran (Toronto: University of Toronto Press, 1992), pp. 50-56, 527-528. 
entity from the others, despite the fact that any particular actual entity must have incorporated and will continue to incorporate other past actual entities into its very identity through the process of concrescence.

There are some important differences, however, as Whitehead quickly notes, between his conception of creativity and Aristotle's notion of matter: "But it [i.e., creativity] is divested of the notion of passive reception, either of 'form,' or of external relations; it is the pure notion of the activity conditioned by the objective immortality of the actual world - a world which is never the same twice, though always with the table element of divine ordering." ${ }^{30}$ For Aristotle, matter is the passive principle with some inertia inherently built into it. Whitehead's creativity, by contrast, is the principle of activity that makes possible the creative advance of the universe. Within the Category of the Ultimate it is creativity that plays an active role in the process of both concrescence and transition, as well as in the movement back and forth between the 'many' and the 'one.' Thus, Aristotle's matter lacks an inherent dynamism that is found in Whitehead's creativity.

From the perspective of Whitehead's general metaphysics, his notion of creativity as a rough rendering of Aristotle's matter may be somewhat confusing because he also includes in his scheme the concept of eternal objects that seems to be approximately equivalent to that of forms in traditional metaphysics. A much closer parallel to Aristotle's notion of matter could have been that of actual entity since they are both apparently to be characterized and defined by forms or eternal objects. This way of thinking, however, might lead one to commit the fallacy of misplaced concreteness because it sees actual entities more as "things" rather than moments of experience. ${ }^{31}$ If actual entities for Whitehead are essentially actions or decisions, hence creativity, then it is a legitimate move when he renders the notion of creativity equivalent to Aristotle's concept of matter. ${ }^{32}$

30 Alfred North Whitehead, Process and Reality, p. 31.

31 See Alfred North Whitehead, Process and Reality, p. 78.

32 See Gene Reeves, "God and Creativity," in Explorations in Whitehead's Philosophy, edited by Lewis S. Ford and George L. Kline (New York: Fordham University Press, 1983), p. 242. 
In this scheme it is actual entities as activity or dynamism, not as concrete things, that are characterized by the potentialities and values of eternal objects.

\section{CREATIVITY AND GOD}

Given the important role that creativity plays in the creative advance of the universe, one may wonder about the place of God in Whitehead's metaphysical scheme. The relation between creativity and God is indeed one of the most important issues in this kind of philosophy. There is no doubt that both creativity and God play a decisive role in the emergence of new actual entities. Sherburne calls these factors, together with eternal objects, three "formative" elements in the "making" of actual entities. Only by analyzing the function of these formative elements and their mutual relationship can we better understand the nature of the actual entities they form. ${ }^{33}$

In Process and Reality the relationship between creativity and God is described in several ways: God is the "primordial, non-temporal accident" of creativity ${ }^{34}$; God is "the primordial creature," "the outcome of creativity, as the foundation of order, and as the goad towards novelty"35; God's primordial nature is "the acquirement by creativity of a primordial character" ${ }^{\prime 36}$ For Whitehead, first of all, creativity is not a principle that is above and beyond God. Insofar as God is himself an actual entity ${ }^{37}$, God partakes in the inherent dynamism that exists in all actual entities. This is what Whitehead means when he describes God as a "creature" or the "outcome of creativity." This description of God suggests that each actual entity, including God, is the outcome of a creative process, its internal process of self-creation. As an actual entity, God is "subject," so to speak,

33 Donald W. Sherburne, A Key to Whitehead's Process and Reality, p. 20.

34 Alfred North Whitehead, Process and Reality, p. 7.

35 Alfred North Whitehead, Process and Reality, p. 88.

36 Alfred North Whitehead, Process and Reality, p. 344.

37 Alfred North Whitehead, Process and Reality, p. 18. 
to the dynamic self-creating process that is exemplified in every actual entity. God is not standing above the principle of creativity that God primordially exemplifies: "Every actual entity, including God, is a creature transcended by the creativity which it qualifies." 38

In Whitehead's scheme, however, there is a certain aspect in God's nature that distinguishes Godself from other actual entities. God's primordial nature, as Whitehead conceives it, grants God a special function to decide which of the eternal objects are to be realized in the creative process. It is the "reservoir" of the general potentiality of the universe. Different from the temporal actual entities, God is "the actual entity in virtue of which the entire multiplicity of eternal objects obtains its graded relevance of each stage of concrescence." 39 Thus, for Whitehead, God is the supreme instance of creativity, without which no other instance of creativity is possible. Through his primordial nature, God serves as the principle that determines the direction of the effect of creative process, hence the "principle of concretion." ${ }^{40}$ We can say that God, creativity, and actual entities (or "creatures" insofar as these entities are in the creative process of self-actualization) presuppose each other: "There is no meaning to 'creativity' apart from its 'creatures,' and no meaning to 'God' apart from 'creativity' and the 'temporal creatures,' and no meaning to the 'temporal creatures' apart from 'creativity' and 'God.'”41

We find in Whitehead's speculative philosophy, therefore, that the role and function of God is distinct from what is traditionally given. Despite being "the eternal primordial character" of creativity ${ }^{42}$, God remains simply one of the actual entities. Thus, God is not standing above

38 Alfred North Whitehead, Process and Reality, p. 88.

39 Alfred North Whitehead, Process and Reality, p. 164, italics original.

40 Alfred North Whitehead, Process and Reality, p. 345.

41 Alfred North Whitehead, Process and Reality, p. 225.

42 The complete description of this attribute is the following: "The true metaphysical position is that God is the aboriginal instance of this creativity, and is therefore the aboriginal condition which qualifies its action. It is the function of actuality to characterize the creativity, and God is the eternal primordial character." Alfred North Whitehead, Process and Reality, p. 225. 
and beyond creation as usually understood in traditional metaphysics: "He is not before all creation, but with all creation." 43 That is to say, God in Whitehead's metaphysics is not a transcendent creator, but rather the supreme principle of creativity which determines all the actual entities and is conceived as purely immanent. ${ }^{44}$ In this scheme, the kind of God required is not a Creator-God, since every actual entity is self-creating, but rather a God who guarantees the continuing process of creative advance and order.

In his article on God and creativity, Stephen T. Franklin explains the main reason for the move made by process thinkers, including Whitehead, to separate creativity from God, namely, to "preserve the freedom of the creatures." 45 Process thinkers, he says, tend to see the traditional understanding of a Creator-God as compromising the freedom and autonomy of the creatures. The doctrine of creatio ex nihilo, for instance, does not take seriously the inherent character of self-causation among the creatures: "The freedom inherent in the universe is constituted by this element of self-causation." ${ }^{46}$ As a result, the creatures may seem to have a certain power of causation and yet to lack genuine freedom. The separation between God and creativity, according to these thinkers, allows the creatures (or actual entities in the Whiteheadian scheme) to be fully autonomous (yet interrelated among themselves) and free in deciding their future on the basis of their own subjective aim. That is why in the Whiteheadian perspective every actual entity always has decisions to make, both with regard to the past actual entities it incorporates into itself and to its present state.

There is another reason behind the presentation of God as the primordial instance of creativity, instead of as the ultimate source of creativity itself. Whitehead does not want to have a notion of God in his

43 Alfred North Whitehead, Process and Reality, p. 343.

44 Cf. Alfred North Whitehead, Process and Reality, p. 32.

45 Stephen T. Franklin, "God and Creativity: A Revisionist Proposal within a Whiteheadian Context," Process Studies 29/2 (2000): 237-238.

46 Alfred North Whitehead, Process and Reality, p. 88. 
system in which God stands above all metaphysical principles and has nothing to do with the actual happenings in the universe. Nor does he wish, as it often occurs, that this God be invoked only to fill the metaphysical gap or to secure the ontological foundation of the world, which otherwise would be shaky. That is why in his treatment of God and the world towards the end of Process and Reality, he warns, "God is not to be treated as an exception to all metaphysical principles, invoked to save their collapse." 47 In Science and the Modern World, Whitehead speaks against such a tendency and sees it as an anti-rational approach:

My point is that any summary conclusion jumping from our conviction of the existence of such an order of nature to the easy assumption that there is an ultimate reality which, in some unexplained way, is to be appealed to for the removal of perplexity, constitutes the great refusal of rationality to assert its rights. ${ }^{48}$

By making creativity, instead of God, the ultimate reality to be appealed to "for the removal of perplexity," I think, on the one hand, Whitehead is successful in showing that one does not need an external source or cause such as God to explain the reality of creative advance that takes place in the universe. Creativity as the ultimate metaphysical category is not to be found outside the universe nor brought in simply "to avoid the collapse of a metaphysical system," but rather finds its intrinsic place in every actual entity as a dynamic principle that makes self-creation and actualization possible. ${ }^{49}$ This solution, on the other hand, may create a rather complex problem, as we will see below, regarding the ontological status of creativity itself. In this regard, one may raise the question of why there is a dynamic process such as creativity at all in every actual entity.

47 Alfred North Whitehead, Process and Reality, p. 343.

48 Alfred North Whitehead, Science and the Modern World, p. 92.

49 See Kenneth F. Thompson, Jr., Whitehead's Philosophy of Religion (The Hauge: Mouton, 1971), p. 111. 


\section{The Separation Between Creativity and God}

Before getting into a more detailed analysis of the relationship between creativity and God, let us take a look at the double character of God, which also seems to give rise to a problem in Whitehead's metaphysics. As an actual entity, God is both a creature of creativity and condition for

creativity. ${ }^{50}$ For the latter's function, God is eminently the principle of concretion. ${ }^{51}$ The problem emerges as to how an actual entity (as God is) is at the same time a principle of concretion for the creative emergence of new actual entities. God may be a primordial actual entity different from temporal actual entities. Nevertheless, God remains an actual entity that is in some respect defined and determined by other actual entities. One may object to the Whiteheadian position by arguing that the ground for all determinant actual entities cannot itself be just another determinant entity.

Some Whiteheadian scholars and critics find the roots of this sort of problem in the Whiteheadian separation of God and creativity. By assigning the ultimate metaphysical principle to creativity instead to God, Whitehead faces a problem concerning the ontological foundation of the principle of creativity itself. Robert C. Neville makes a distinction between two types of creativity, namely, cosmological and ontological. Cosmological creativity explains the unity of an actual entity on the basis of the Whiteheadian understanding of the ontological principle, according to which the ultimate reason for creativity is to be found in the actual entity itself. This unity can be explained in terms of the decisions made by the actual entity with regard to the past actual entities it prehends and to its own concrescence. ${ }^{52}$ Ontological creativity, by contrast, should answer the question "why there is any decision at all, why any eternal objects ingress, why there is any objectification of actual entities, or why there are any actual entities." 53

50 Alfred North Whitehead, Process and Reality, p. 31.

51 Alfred North Whitehead, Process and Reality, pp. 244, 345.

52 Robert C. Neville, "Whitehead on the One and the Many," pp. 258-259.

53 Robert C. Neville, “Whitehead on the One and the Many," p. 259. 
These questions, according to Neville, are generally associated with ontology. Whitehead's ontological principle, however, does not answer those questions, but rather merely explains how the concrescence process takes place or how the ingression of eternal objects occurs. The task of addressing the proper ontological questions in Whitehead's scheme is relegated to the Category of the Ultimate. For Neville, what Whitehead calls "ontological principle" is actually a "cosmological principle" because it addresses the constitution of the actual entities in the universe. With regard to the Category of the Ultimate, one may further ask what is "responsible" for the unity of one and many through creativity, because "the decisions of all actual entities, precisely because they are creative, cannot constitute the ontological unity as the condition for creativity." 54 Neville rules out the possibility of God's primordial decision to constitute this ontological unity because that decision, being creative, would depend on a prior ontological unity of many and one in creativity. He concludes that given the ontological principle, the ontological unity of the one and the many through creativity in the Category of the Ultimate is impossible. ${ }^{55}$ He further offers an alternative conception of creativity as "the bringing about of a many in an act that constitutes the creative source to be a unified agent, a one for the created product." In this conception, creativity is not defined on a par with one and many nor is the product of their mutual interrelation. By the appeal to the ontological creativity, Neville argues, one may understand how the world, as Whitehead describes it, is possible, that it is "ontologically created, not by decisions within its own process - that would be self-referentially absurd - but by a transcendent creator who makes himself creator in the act of creating." 56

One of the larger issues that lurks behind Neville's critique of Whitehead's metaphysics, in my opinion, concerns what exactly Whitehead is doing in his project. Neville argues, as we have seen above, that Whitehead only explains the "how" of things in the universe

54 Robert C. Neville, "Whitehead on the One and the Many," p. 265.

55 Robert C. Neville, "Whitehead on the One and the Many," pp. 265-266.

56 Robert C. Neville, "Whitehead on the One and the Many," p. 267. 
characterized by creativity but never explicates the "why" of things as they are. ${ }^{57}$ Whitehead's supposedly ontological principle seems to be found within the cosmological frame of reference. For Neville, this kind of selfreferencing may be acceptable as cosmology but not as ontology or speculative metaphysics. If Neville's charge is correct, one may raise the question of what precisely Whitehead is doing in his work, particularly in Process and Reality: speculative philosophy or metaphysics as he purports in the first pages of the book, or cosmology, which is evident from the subtitle and can be largely found in his earlier work such as Science and the Modern World. There is no doubt that Whitehead has a great interest in cosmology. The question is whether this great interest somehow becomes the source of confusion on his part regarding metaphysics, ontology and cosmology. This is indeed an interesting topic to discuss, but it is definitely larger than the scope of this article and would require a special study.

\section{CONCLUSION}

Whitehead's metaphysical scheme in general, as an alternative to modern metaphysics, is relatively solid and comprehensive. A good number of new terms are coined to better express his philosophical system, which attempts to take modern science into account. His use of the category of the actual entity, for instance, purports to replace the traditional concept of substance as well as to avoid the fallacy of misplaced concreteness that permeates traditional metaphysics. Likewise, he employs the category of creativity as the ultimate universal concept expressing both the process of becoming, which is characteristic of all events, and the origination of novelty. Creativity is not simply a universal concept descriptive of the substantial activity of all actual entities but rather points to the inherent

57 It is important to note that the role of God in Whiteheadian process philosophy may be greater than that presented in this article. An exhaustive treatment of God may indeed help account for the 'why' of the world, which is beyond the scope of this article. For explicit roles of God in this philosophy, one may read Charles Hartshorne's article "God as Composer-Director, Enjoyer, and, in a sense, Player of the Cosmic Drama," Process Studies Vol. 30/2 (Fall-Winter, 2001): 242-260. 
dynamism of the entities in a self-creative process. In some respects, Whitehead's notion of creativity is similar to Aristotle's conception of matter, in that it requires characterization from eternal objects (or "forms" in Aristotle) in order to emerge as an ever becoming actual entity. Aristotle's matter, however, is essentially passive receptive whereas Whitehead's creativity is actively creative.

In Whitehead's metaphysics creativity has its own independent status, though not unrelated to God, and God is not the principal source of creativity as usually seen in traditional metaphysics. Whitehead's concept of creativity is essentially established to accommodate the idea that every process is active in and of itself (causa sui) without the intervention of a transcendent creator. The separation between creativity and God in this scheme may cause some problems, as Neville points out for instance, that there is no ontological principle to appeal to in the Category of the Ultimate, regarding the interaction of one and many through creativity. Further questions may also be raised concerning the nature of Whitehead's project, namely, whether it is intrinsically ontology as traditionally understood or simply cosmology with some philosophical categories. This question may not find an easy answer, since philosophy and science gernerally, and particularly in Whitehead, have a common object of investigation, namely, the processes of the physical world. The fundamental terms in this kind of philosophy (e. g. creativity) may not be easy to grasp, and can even be elusive in this context. This problem and other conceivable ones, however, should not obscure Whitehead's great accomplishment in interpreting reality and producing a philosophy that is faithful to the depths of our own experience. His account of creativity fundamentally reminds us of the 'becoming' of the universe and ourselves as well as of the pervasive creative advance that occurs in our midst.

\section{REFERENCES}

Christian, William A. An Interpretation of Whitehead's Metaphysics. New Haven: Yale University Press, 1967.

. "The Concept of God as A Derivative Notion." In Process and Divinity: Philosophical Essays presented to Charles Hartshorne. 
Edited by William L. Reese and Eugene Freeman. LaSalle, IL: Open Court, 1964, pp. 181-203.

Ford, Lewis S. and George L. Kline, eds. Explorations in Whitehead's Philosophy. New York: Fordham University Press, 1983.

Franklin, Stephen T. "God and Creativity: A Revisionist Proposal within a Whiteheadian Context" Process Studies, 29/2 (2000): 237-307.

Rapp, Friedrich and Reiner Wiehl, eds. Whitehead's Metaphysics of Creativity. Albany: State University of New York Press, 1990.

Rickards, Tudor, Mark A. Runco and Susan Moger, eds. The Routledge Companion to Creativity. London and New York: Routledge, 2009.

Ross, Stephen David. Perspective in Whitehead's Metaphysics. Albany: State University of New York Press, 1983.

Runco, Marc A. and Steven R. Pritzker. Encyclopedia of Creativity, 2 vols., second edition. London: Elsevier, 2011.

Sherburne, Donald W., ed. A Key to Whitehead's Process and Reality. Chicago: The University of Chicago Press, 1981.

Thompson, Jr., Kenneth F. Whitehead's Philosophy of Religion. The Hauge: Mouton, 1971.

Whitehead, Alfred North. Process and Reality: An Essay on Cosmology. Edited by David Ray Griffin and Donald W. Sherburne. Corrected edition. New York: The Free Press, 1978.

Science and the Modern World. New York: The Free Press, 1967.

Wilcox, John R. "A Monistic Interpretation of Whitehead's Creativity." Process Studies 20/3 (Fall 1991): 162-174. 